\title{
PALYNOLOGY AND THE NETHERLANDS
}

\author{
F. P. JONKER \\ President, Second International Conference on Palynology, Utrecht, 1966 \\ Botanical Museum and Herbarium, State University, Utrecht (The Netherlands)
}

(Received August 25, 1966)

\section{SUMMARY}

A description is given of the history of the development of palynology in The Netherlands. This development is traced from the appearance in 1777-1779 of the book Katechismus der Natuur by J. F. Martinet, through the increased interest, begun in the 1920's with the appearance of a thesis by Miss B. Polak on the investigation of peat bogs in the western Netherlands, to the culmination with the establishment of palynological divisions in several universities and other institutions in The Netherlands.

\section{J. F. MARTINET}

The first Dutchman who paid attention to the morphology and dispersal of pollen grains was Johannes Florentinus Martinet, born in 1729, in his time a well-known clergyman in the provincial town of Zutphen in the eastern part of The Netherlands. He finished his theological studies in the University of Leiden and, moreover, took a philosophical doctor's degree on a thesis dealing with the respiration of insects. He was, successively, a clergyman in the village of Gellikum and in the little town of Edam and was called in 1775 to Zutphen where he ministered his parish until his death in 1795. At Zutphen he wrote his Katechismus der Natuur (Catechism of Nature), which appeared in the period from 1777 to 1779. Of this book, in four volumes, four editions appeared during Martinet's life and, moreover, one after his death. It was widely read and translated into a number of languages. It discussed nature and natural phenomena in the form of conversations between a master and his pupil. In the fourth volume flower morphology, pollen dispersal, pollination and pollen morphology are discussed coming to the conclusion that God had prodigiously foreseen all environmental and morphological variability. Plate I shows very primitive illustrations of fifteen pollen grains, which were published in his book. 


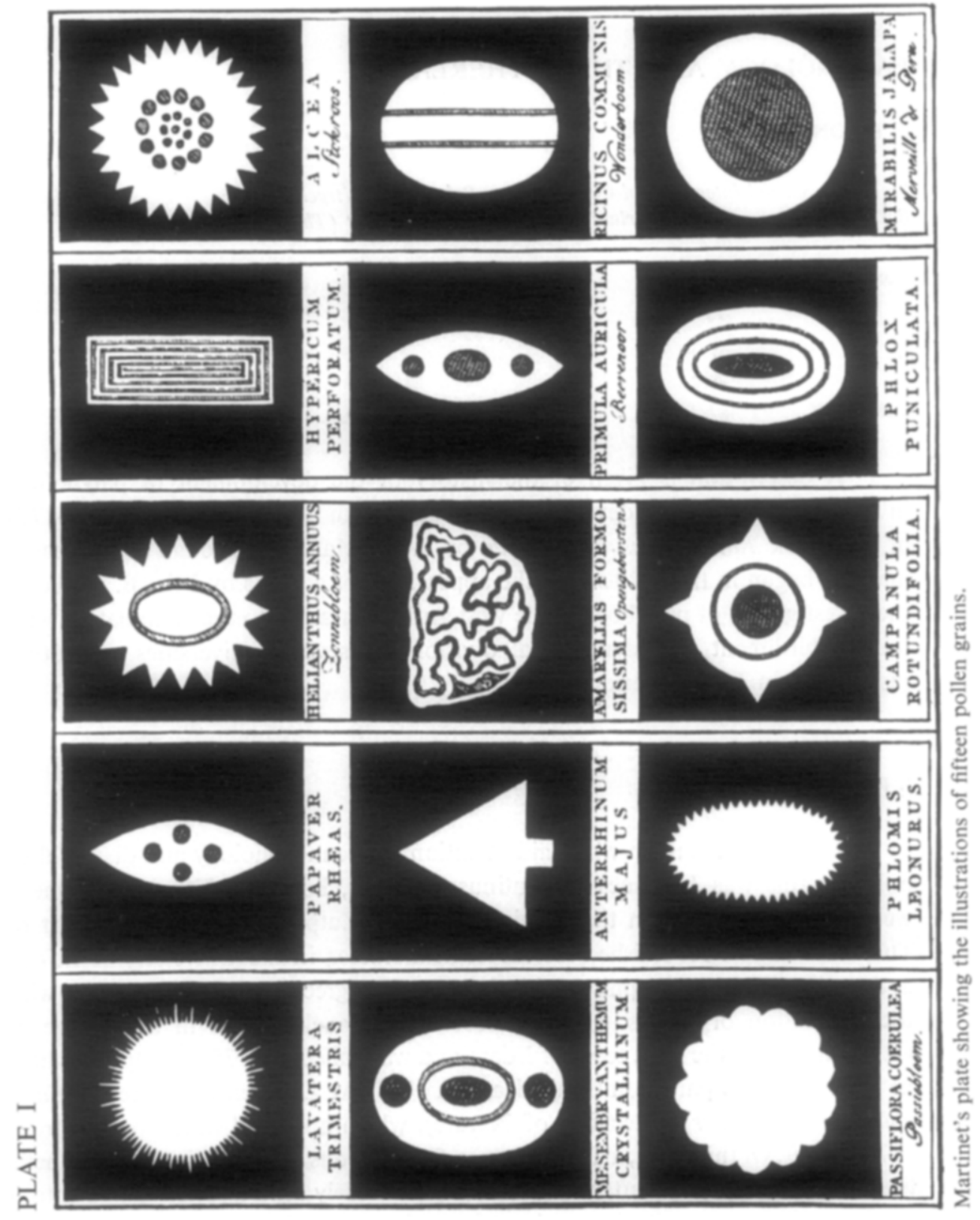


Scientific pollen analysis started in The Netherlands shortly after the publications by the Swedish pioneers. In the nineteen twenties, two centres originated contemporaneously, viz. at the University of Amsterdam and at the State University in Utrecht. In Amsterdam, Miss Betje Polak published her doctorial thesis dealing with the investigation of peat bogs in the western part of The Netherlands in 1929. It was soon followed by a second thesis by Mrs. VermeerLouman, 1934, who also investigated interglacial peat deposits. But then the palynological research at the University of Amsterdam temporarily stopped. At the Botanical Museum and Herbarium of the State University, Utrecht, F. Florschütz started his work in the late nineteen twenties with a number of students and co-workers, resulting in numerous publications. Florschütz was a jurist, and secretary of the Board of Governors of the Agricultural University in Wageningen. As he took a keen interest in both botany and geology he started his studies in biology at the State University, Utrecht, and in that way he got on the track of pollen analysis which fascinated him from the beginning. Once a week he came to Utrecht and fired numerous students with enthusiasm toward the young science. At his house in the village of Velp near Arnhem he did, moreover, much research as well. This private laboratory acquired an official recognition after the Second World War when he was relieved of his functions at Wageningen.

In 1947, he was awarded a honorary doctor's degree in the Utrecht University, which degree he obtained in the same hall as in which the opening ceremony of the Second International Conference on Palynology took place.

In that time, however, he transferred his activities from the Utrecht Botanical Museum to the Geological Institute of the State University in Leiden. There he started to train the geological students in palynology. In 1948, he became a special Professor of Palaeobotany and Palynology in that university. The direction of the palaeobotanical and palynological research at Utrecht was, after the departure of Florschütz, taken over by F. P. Jonker, now a Professor of Special Botany in this university.

A special merit of Florschütz was his realization of the importance of palynology to oil exploration. This led to the start and the development of palynological research in the laboratories of the B.I.P.M./Shell Group both in The Netherlands and abroad.

In the fifties Florschütz started, with Professor Menendez Amor of Madrid, together with a number of his Leiden students, extensive pollenanalytical investigations in Spain and some other localities in the Mediterranean. This work is still in course of continuation by the Leiden palynologists. After his retirement from Leiden Florschütz became a honorary lecturer in the University of Nijmegen. There, again he introduced the methods of palynology to students of biology. At the same time he continued his work in Spain. The Second International Con- 
ference on Palynology nominated this pioneer of palynology in The Netherlands its Honorary President. He died, however, the 21 st of July, 1965, at Velp, at the age of 78 years.

TOWARDS THE PRESENT SITUATION

After Florschütz's retirement, the palynological centre in the Geological Institute of the State University in Leiden was under the direction of T. van der Hammen. Another Leiden centre arose in the State Museum of Geology and Mineralogy. Recently these two Leiden centres have been united in the State Museum of Geology and Mineralogy. Research is carried out in the fields of both Quaternary and pre-Quaternary palynology and in fluorescence palynology. The special interest of a number of workers is centred round the vegetational successions in South America next to palynological research in the Alps, the Mediterranean and, of course, in The Netherlands.

The centre in the Botanical Museum and Herbarium of the State University in Utrecht developed into a Division of Palaeobotany and Pollen Morphology, in a separate building. Next to macro-palaeobotany, investigations are carried out in both Quaternary and pre-Quaternary palynology and in pollen morphology.

At the University of Amsterdam, pollen morphological work is done now in the Hugo de Vries Laboratory of Special Botany. Quaternary pollen analysis is carried out both in the Institute of Physical Geography and-with special reference to archaeology-in the Institute of Prae- and Protohistory.

In the Botanical Institute of another Amsterdam University - the Free University - some work is done in the field of pollen dispersal.

At the State University in Groningen, an important centre, now under the direction of H. T. Waterbolk and W. van Zeist, arose during the Second World War, in the Department of Biological Archaeology. Research in Quaternary palynology and Quaternary ethnobotany is carried out, chiefly in The Netherlands but also abroad, especially in the Mediterranean and the Near East. Well-known to palynologists of all the world is the centre for radiocarbon dating of the State University in Groningen. It was started by Professor Hl. de Vries who developed a series of ingenious methods. After his death, in 1959, the work is continued under the direction of J. C. Vogel.

In the Department of Pedology of the Agricultural University, Wageningen, Miss B. Polak, next to Florschütz a pioneer in The Netherlands, is conducting Quaternary palynology, often in cooperation with the Soil Survey of The Netherlands. Important investigations are also carried out on pollen corrosion.

In the Botanical Laboratory of the University of Nijmegen some work is done in Quaternary palynology and pollen dispersal. Very extensive research is 
carried out both in electron-microscopical palynology and in the physiology of pollen germination.

Another important centre arose after the Second World War in the Geological Survey at Haarlem. There W. H. Zagwijn carried out his well-known research in Late Tertiary and Pleistocene palynology. At present a number of palynologists are working both in Quaternary and in Tertiary palynology and recently also pre-Tertiary research has been added.

The work on megaspores by S. J. Dijkstra at the Geological Bureau of the Mining District, at Heerlen, is also well-known. Occasionally other pre-Quaternary palynological investigations are carried out.

In the laboratories of B.I.P.M. and Shell, at The Hague and Rijswijk and in a number of overseas countries various pre-Quaternary deposits are under research and, moreover, some work is done in statistical palynology and in fluorescence microscopy.

A small number of medical men are carrying out investigations in pollen and spore morphology and pollen and spore dispersal with special reference to allergy. 